\title{
Inflammatory rectal polyp with osseous metaplasia
}

\section{Kemik metaplazisinin eşlik ettiği inflamatuvar rektal polip}

\author{
Ebru ZEMHERi ${ }^{1}$, Mehtap TOPRAK ${ }^{1}$, PInar ENGIN ZERK ${ }^{1}$, Seyma OZKANLi ${ }^{1}$, Murat MUTUS ${ }^{2}$
}

\section{SUMMARY}

To present a rare case of osseous metaplasia in an inflammatory rectal polyp. A 9-year-old boy admitted to the clinic with a 6 month history of intermittent rectal bleeding that occurred approximately 15 times. An $8 \mathrm{~mm}$ polyp in diameter was totally excised from rectal wall. Histologically, elongated, dilated, mucin filled colonic glands were scattered within stroma which was composed of both acute and chronic inflammatory and granulation tissue. In the stroma there was a small focus of new bone formation, which was covered with intact colonic mucosa. We presented an extremely rare case report of a metaplastic bone formation in a rectal inflammatory polyp.

Key words: Rectum, osseous metaplasia, inflammatory polyp

\section{INTRODUCTION}

Osseous metaplasia is a heterotopic bone formati$\mathrm{on}^{1}$. While it is rarely seen in various types of polyps of the stomach, colon, and rectum of the gastrointestinal tract, its occurrence in colonic polyps is extremely rare ${ }^{2-4}$. Mark, in 1964, firstly descripted bone formation within a rectal polyp ${ }^{4}$. The mechanism of this metaplastic change has not been completely understood $^{1-3}$. Clinically and prognostically, its significance is not known ${ }^{1}$.

Herein, we report a case that is osseous metaplasia in an inflammatory rectal polyp in a 9-year-old boy with an accompanying literature review.

\section{CASE REPORT}

A 9-year-old boy admitted to the clinic with a 6-
ÖZET

Ender bir olgu olan "inflamatuvar rektal polipte osseöz metaplazi" sunumu. Dokuz yaşında erkek hasta 6 aydır ara ara olan yaklaşık 15 kez yineleyen rektal kanama yakınmasıyla başvurdu. Rektal duvardan $8 \mathrm{~mm}$ çapta polip eksize edildi. Histolojik olarak, akut ve kronik inflamasyon ve granülasyon dokusunda oluşan stromada dağınık uzamış, genişlemiş, müsinle dolu kolonik glandlar görüldü. Stromada küçük bir odakta normal kolonik mukoza ile çevrili yeni kemik oluşumu dikkati çekti. Oldukça ender görülen rektal inflamatuvar polipte metaplastik kemik oluşumu olgusu literatür bilgileri ile sunuldu.

Anahtar kelimeler: Rektum, osseöz metaplazi, inflamatuvar polip

month history of intermittent rectal bleeding which was independent from defecation and occurred approximately 15 times during this period and. The bleedings were light colored drips without coagulum. Hemorrhoid or anal fissure formation was not detected during digital anal examination, and only a suspect lesion could be palpated. Biochemical test results were within normal limits. A flexible colonoscopic examination was performed and the only pathologic finding was a polyp $8 \mathrm{~mm}$ in diameter which was totally excised from the rectal wall (Figure 1). During one year of follow up period, the patient was free of any symptoms.

On gross examination, tan-brown colored polypoid mass, which was $0.8 \mathrm{~cm}$ in diameter, was seen. It was bisected on its long axis and submitted for histological examination. Microscopically, surface of the polyploid mass was covered by fibrinopurulent

Received: 24.07.2015

Accepted: 21.08.2015

${ }^{1}$ Istanbul Medeniyet University, Goztepe Training and Research Hospital, Department of Pathology

${ }^{2}$ Istanbul Medeniyet University, Goztepe Training and Research Hospital, Department of Pediatric Surgery

Yazışma adresi: Dr. Seyma Ozkanli, Tutuncu Mehmet Efendi Cad. Karanfil Sok. Ugur Apt:16/3, Goztepe-Istanbul

e-mail: seymaozkanli@gmail.com 


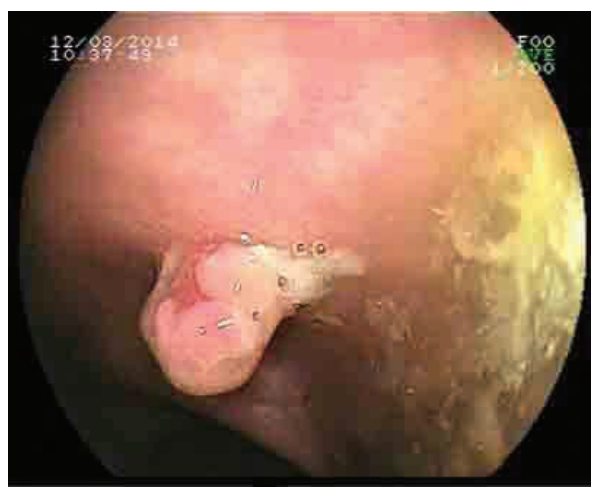

Figure 1. Rectal polyp on endoscopic examination.

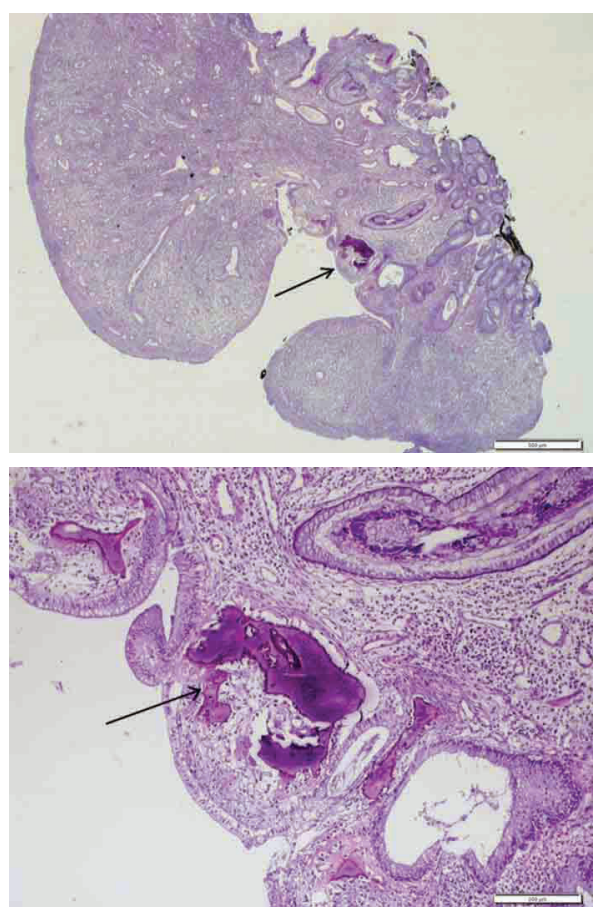

Figure 2A. Inflammatory polyp with osseous metaplasia (arrow)(H\&Ex20), B. Bone trabecula in polyp stroma (arrow) (H\&Ex100).

debris. Elongated, dilated, mucin filled colonic glands were scattered within stroma which was composed of both acute and chronic inflammatory and granulation tissue (Figure 2A). In the stroma, there was a small focus of new bone formation that was covered with intact colonic mucosa (Figure 2B). Bone marrow cells were not visible.

\section{DISCUSSION}

Osseous metaplasia in colonic polyps is extremely rare. In English-written literature, only twenty-one cases have been reported up to date together with our case. We reviewed and summarized the subject of osseous metaplasia in colon polyps (Table 1). The patients comprised thirteen men and five women, besides two whose genders were not described. The mean age of the patients was 69 yeras (range: 3-85 years). Mean diameter of polyps was $16.3 \mathrm{~mm}$ (range: 8-50 mm). Histologically, six lesions were neoplastic (three tubular adenomas and three tubulovillous adenomas), while the remaining fifteen lesions were non-neoplastic entities (six inflammatory polyps, seven juvenile polyps and one traditional serrated adenoma). Site of involvement was rrectum-rectosigmoid $(n=16)$, sigmoid colon $(n=2)$, cecum $(n=1)$, and transverse colon $(n=1)$.

Osseous metaplasia can be seen in both benign and malignant conditions. The pathogenesis of osseous metaplasia remains unknown. Many theories have been published concerning its pathogenetic mechanism.

Osteogenic stimulation was considered as the result of inflammatory process ${ }^{2}$. Necrosis, inflammation, pre-existing calcification, increased vascularity and extracellular mucin deposition are reported to be associated with heterotopic bone formation in tumors ${ }^{7}$. Both benign and malignant lesions with osseous metaplasia are commonly associated with mucin production and extravasations. Benign lesions with osseous metaplasia are often seen with active chronic inflammation and or ulceration ${ }^{7,8,13}$. In 1939, Dukes reported a case series of osseous metaplasia in rectal carcinoma. In these series, long duration of symptoms, low grade tumors with low metastatic potential and presence of necrosis were shown as contributing factors ${ }^{4}$. He also suggested osseous formation after dystrophic calcification of necrotic tissue $^{4,17}$. In 1964, Marks and Atkinson suggested that osseous metaplasia might result from transformation of fibroblasts into other types of mesodermal tissue, especially osteoblasts ${ }^{4,13}$. In 1989, Randall et al. ${ }^{18}$ showed expression of alkaline phosphate - which is a marker of bone synthesis- in osteoblast- like cells of metaplastic bone and to a lesser degree in glan- 
Table 1. Summary of reported cases of benign colorectal polyps with osseous metaplasia.

\begin{tabular}{lcccccc}
\hline Year & Author & Age & Gender & Site & Size (mm) & Types of Polyp \\
\hline 1964 & Mark (4) & 10 & $\mathrm{M}$ & Rectum & $\mathrm{NI}$ & Juvenile \\
1981 & Sperling (5) & 25 & $\mathrm{M}$ & Rectum & 10 & Inflammatory \\
1992 & Drut (4) & 5 & $\mathrm{M}$ & Rectosigmoid & 10 & Juvenile \\
1992 & Drut (4) & 4 & $\mathrm{M}$ & Rectum & 5 & Juvenile \\
1992 & Castelli (6) & 22 & $\mathrm{~F}$ & Rectum & 10 & Inflammatory \\
1994 & Groisman (7) & 67 & $\mathrm{M}$ & Rectum & 18 & Tubulovillous adenoma \\
1994 & Groisman (7) & 3 & $\mathrm{~F}$ & Rectum & 20 & Juvenile \\
1996 & Cavazza (8) & $\mathrm{NI}$ & $\mathrm{NI}$ & NI & $\mathrm{NI}$ & Tubulovillous adenoma \\
1999 & McPherson (9) & 73 & $\mathrm{M}$ & Cecum & 20 & Tubulovillous adenoma \\
2000 & Rothstein (10) & $\mathrm{NI}$ & $\mathrm{NI}$ & Sigmoid colon & 25 & Tubular adenoma \\
2005 & Al-daraji (11) & 85 & $\mathrm{~F}$ & Sigmoid colon & 15 & Tubular adenoma \\
2008 & White (12) & 63 & $\mathrm{~F}$ & Transverse colon & $\mathrm{NI}$ & Tubular adenoma \\
2009 & Oono (13) & 39 & $\mathrm{M}$ & Rectum & 12 & Inflammatory polyp \\
2009 & Ahmed (14) & 17 & $\mathrm{M}$ & Rectum & 18 & Juvenile retension polyp \\
2010 & Wilsher (15) & 50 & $\mathrm{M}$ & Rectosigmoid & 25 & traditional serrated adenoma \\
2012 & Odum (4) & 74 & $\mathrm{M}$ & Rectum & 10 & Inflammatory polyp \\
2012 & Montalvo (16) & 62 & $\mathrm{M}$ & Rectum & 50 & traditional serrated adenoma \\
2012 & Bhat (2) & 5 & $\mathrm{~F}$ & Rectum & 15 & Juvenile retension polyp \\
2013 & Bhattacharya (3) & 14 & $\mathrm{M}$ & Rectum & 10 & Inflammatory polyp \\
2013 & Garg (1) & 6 & $\mathrm{M}$ & Rectum & Juvenile polyp \\
2014 & Current case & 9 & $\mathrm{M}$ & Rectum & 8 & Inflammatory polyp \\
& & & & &
\end{tabular}

dular cells of metastatic colonic adenocarcinoma and proliferating mesenchymal cells. Recent studies have suggested the role of expression of bone morphogenetic proteins (BMPs) in the pathogenesis of osseous metaplasia ${ }^{19}$. BMPs are members of the TGF $\beta$ superfamily and play a major role in the formation of new bone, except BMP-1 which is a metalloproteinase and a marker for cartilaginous differentiation. In immunohistochemical analysis, BMP-2, BMP-4, BMP-5, and BMP-6 were demonstrated in colonic adenorcacinomas with osseous metaplasia by Imai et al. ${ }^{20}$ In 2001. BMP-2, BMP-4, BMP-5, and BMP-6 were found to be present in the cytoplasm of tumor cells and within the osteoblast-like cells of newly formed bone, and BMP-2 and BMP-4 were shown in stromal fibroblasts. In 2007, Liu et al. ${ }^{19}$ immunohistochemically demonstrated expression of BMP-1, BMP-4 and BMP-6 in both stroma and epithelium in various cases with osseous metaplasia.

Pathogenesis of osseous metaplasia is still under investigation. Its exact in vivo pathogenetic mechanism is still unknown but in vitro studies which were done with mouse and human fibroblast cultures showed that four transcription factors (Oct $3 / 4$, Sox-2, c-myc,
KIf4) are related with the production of pluripotent stem cells. Subsequently, these stem cells are shown to differentiate into different cell types of all three germ layers ${ }^{21,22}$.

An osseous metaplasia is an incidental finding and it is clinically and prognostically insignificant. Its exact pathogenesis is unknown but transformation of the fibroblasts into osteoblasts is suggested. Here, we presented an extremely rare case of a metaplastic bone formation in an inflammatory rectal polyp.

\section{REFERENCES}

1. Garg M, Kaur J, Bindroo S, et al. Metaplastic Ossification in a Juvenile Rectal Polyp: A Rare Histological Finding. Journal of Clinical and Diagnostic Research 2013; 7: 908-910. http://dx.doi.org/10.7860/jcdr/2013/5403.2972

2. Bhat V, AN N R, Shariff S. Juvenile Rectal Polyp with Osseous Metaplasia - A Rare Case with Review of Literature. International Journal of Health Sciences \& Research 2012; 2: 114-116.

3. Bhattacharya N, Sarkar T. Osseous Metaplasia in A Juvenile Polyp: A Rare Case Report in India. Journal of Clinical and Diagnostic Research 2013; 7: 2004-2005. http://dx.doi.org/10.7860/jcdr/2013/5789.3385

4. Brian R. Odum, Matthew L. Bechtold, Alberto Diaz-Arias. Osseous Metaplasia in an Inflammatory Polyp of the Rectum: A Case Report and Review of the Literature. Gastroenterology Research 2012; 5: 74-78.

5. Sperling $\mathrm{MH}$, Friedman $\mathrm{CJ}$. Osseous metaplasia in a benign 
colon polyp. Gastrointest Endosc 1981; 27: 198-99. http://dx.doi.org/10.1016/S0016-5107(81)73199-7

6. Castelli MF, Roberts J. Ossification in a benign rectal polyp. Am J Gastroenterol 1992; 87: 543-44.

7. Groisman GM, Benkov KJ, Adsay V, et al. Osseous metaplasia in benign colorectal polyps. Arch Pathol Lab Med 1994; 118: 64-65.

8. Cavazza A, Sassatelli R, De Marco L. Bone metaplasia in adenomatous intestinal polyp. Report of a case and review of the literature. Pathologica 1996; 88: 511-13.

9. McPherson F, Maldonado M, Truitt CA, et al. Metaplastic ossification of a benign colonic polyp: case report. Gastrointest Endosc 1999; 49: 654-56. http://dx.doi.org/10.1016/S0016-5107(99)70402-5

10. Rothstein RD, LiVolsi VA. Metaplastic ossification of a benign colonic polyp. Gastrointest Endosc 2000; 51: 254. http://dx.doi.org/10.1016/S0016-5107(00)70173-8

11. Al-Daraji WI, Abdellaoui A, Salman WD. Osseous metaplasia in a tubular adenoma of the colon. J Clin Pathol 2005; 58: 220-21. http://dx.doi.org/10.1136/jcp.2004.020685

12. White V, Shaw AG, Tierney GM, et al. Osseous metaplasia in an ulcerating tubular adenoma of the colon: a case report. $J$ Med Case Rep 2008; 2: 130.

http://dx.doi.org/10.1186/1752-1947-2-130

13. Oono $\mathrm{Y}, \mathrm{Fu} \mathrm{K}$, Nakamura $\mathrm{H}$, et al. Bone formation in a rectal inflammatory polyp. World J Gastrointest Endosc 2010; 2: 104-106. http://dx.doi.org/10.4253/wjge.v2.i3.104

14. Ahmed R, Ahmad Z, Qureshi A. Osseous metaplasia in a juvenile retention polyp: a case report. BMJ Case Rep 2009;2009
15. Wilsher MJ, Mendelsohn GB. Osseous metaplasia in a traditional serrated adenoma of the rectosigmoid colon. Pathology 2010; 42: 302-304. http://dx.doi.org/10.3109/00313021003631221

16. Montalvo NF, Beltrán JN and Redrobán LA. Traditional serrated adenoma of the sigmoid colon with osseous metaplasia: a case report. Journal of Medical Case Reports 2012; 6: 133. http://dx.doi.org/10.1186/1752-1947-6-133

17. Hjelkrem M, Fair K, Pabby A. Osseous Metaplasia in a Colon Polyp. Pract Gastroenterol 2012; 36: 58-62.

18. Randall JC, Morris DC, Tomita T, et al. Heterotopic ossification: a case report and immunohistochemical observations. Hum Pathol 1989; 20: 86-88. http://dx.doi.org/10.1016/0046-8177(89)90209-8

19. Liu K, Tripp S, Layfield LJ. Heterotopic ossification: review of histologic findings and tissue distribution in a 10-year experience. Pathol Res Pract 2007; 203: 633-640. http://dx.doi.org/10.1016/j.prp.2007.05.014

20. Imai N, Iwai A, Hatakeyama S, et al. Expression of bone morphogenetic proteins in colon carcinoma with heterotopic ossification. Pathol Int 2001;51:643-648.

http://dx.doi.org/10.1046/j.1440-1827.2001.01243.x

21. Takahashi K, Yamanaka S. Induction of pluripotent stem cells from mouse embryonic and adult fibroblast cultures by defined factors. Cell 2006; 126: 663-676. http://dx.doi.org/10.1016/j.cell.2006.07.024

22. Takahashi K, Tanabe K, Ohnuki M, et al. Induction of pluripotent stem cells from adult human fibroblasts by defined factors. Cell 2007; 131: 861-872. http://dx.doi.org/10.1016/j.cell.2007.11.019 